\title{
Efficacy of Organic Soil Amendments and a Nematicide for Management of Root-Knot Nematode Meloidogyne Spp. of Onion
}

\author{
Iqbal Faruk \\ Plant Pathology Division, Bangladesh Agricultural Research Institute, Gazipur, Bangladesh
}

Email address:

mifaruk2012@yahoo.com

\section{To cite this article:}

Iqbal Faruk. Efficacy of Organic Soil Amendments and a Nematicide for Management of Root-Knot Nematode Meloidogyne Spp. of Onion. American Journal of Bioscience and Bioengineering. Vol. 7, No. 4, 2019, pp. 57-64. doi: 10.11648/j.bio.20190704.11

Received: July 29, 2019; Accepted: August 23, 2019; Published: December 2, 2019

\begin{abstract}
Field experiments were conducted in 2013-14, 2014-15 and 2015-16 planting seasons to evaluate the efficacy of different sources of organic materials and a nematicide Furadan 5G in the control of Meloidogyne incognita infection on the major spices onion, Allium cepa L. The organic materials (poultry refuse, mustard oil cake, rice bran and sawdust) were incorporation with the soil 3 weeks before transplanting of onion seedlings whereas Tricho-composts were added in the soils 5 days before seedling transplanting. The results showed that different organic materials displayed varying levels of effective to the nematode infection. All the treatments gave satisfactory reduction of gall development on roots and increased plant growth as well as yield of onion. Among the treatments, Tricho-composts and poultry refuse appeared to be the best amendments for root knot nematode reduction and significantly influenced the growth of the onion with the highest yield. Saw dust, rice bran and nematicide Furadan $5 \mathrm{G}$ were also proved to be better amendment for reduction of root knot nematode which enhanced plant growth and increased yield of onion. These results suggest that exploitation of organic soil amendment in nematode management would be a useful control measure in onion production in Bangladesh.
\end{abstract}

Keywords: Onion, Tricho-Compost, Organic Materials, Meloidogyne, Nematicide

\section{Introduction}

Onion (Allium cepa L.) is one of the most important and familiar crop spices specially bulb onion through the world. It is a member of the family Alliaceae. It is also used as popular vegetable in many countries of Asia and also very common and favorable spice in Bangladesh. It ranks first in the area (419122 ha) and production (1704402 MT) [1]. It covers almost $46 \%$ of the total areas under spices [1]. The national average yield is only $4.07 \mathrm{t} /$ ha which are quite low compared to world average of 17.27 tha [2]. Onion crops are affected by a number of soil borne and foliar diseases [3-5]. Purple blotch caused by Alternaria porri, is noted as the major foliar disease throughout the world including Bangladesh [5-7]. Common soil-borne diseases of onion are damping-off, pink root and Fusarium basal rot and root knot nematode. Recently, root knot nematode of onion is become destructive and most prevalent where temperatures are 18 to $27^{\circ} \mathrm{C}$, except for Meloidogyne hapla, which is adapted to lower temperatures. A number of phytonematodes are associated with onion roots and soil of onion fields in onion growing countries. The well documented species are Aglenchus siddiqii [8], Ditylenchus dipsaci, Helicotylenchus indicus [9], Meloidogyne incognita [10, 11], M. hepla [12], M. chiwoodi [13], M. arenaria [14], M. graminicola [15], M. javanica,. thamesi, Pratylenchus brachyurus [16]. Among them $M$. incognita and M. graminicola are known as onion root knot nematode, which are the common pest of the crop. Meloidogyne spp. have a wide host range belonging to many plant species but onion is the most suitable host among them [11].

The management of plant parasitic nematodes especially root knot nematode is more difficult in comparison to other pests because they usually live in the soil and attacks the underground parts (roots) of the plant. Further, the enhancement consideration to the environment protection and to human and animal health, which have deeply delimited and revised the use of pesticides on agricultural crops, is stimulating investigation to find new alternative control 
strategies that are environmentally sound and economically convenient at the same time. Therefore, research on small environmental impact alternatives to chemicals has received a strong impulse and considered a wide range of options including agronomical and physical methods (green manures, crop rotations, non-hosts, antagonistic crops, soil amendments, the use of resistant cultivars and arbuscular mycorrhyzal fungi, soil solarization and steam), the use of natural products from plants and biological control agents [17-22] but each method has some limitation to implementation $[23,24]$. The use of resistant cultivars is the most desirable method to reduce the nematode population, particularly because of absent risk to the producer and to the environment [25-27] but the number of resistant and adapted genotypes to the different cultivation regions is limited. Crop rotation including the cultivation of nematode antagonists $[28,29]$ which also promote the improvement of physical, chemical and biological properties of the soil have been suggested for the management of these parasites [30]. But this control method is not always accepted by the producer because they cannot afford to keep areas uncultivated for periods of 60 to 90 days. Therefore, searching for other management alternative is important, and the use of organic soil amendments provides many benefits, such as the increase in the population of natural enemies [31], changes in physical and chemical properties of soil, including base saturation, porosity and conductivity of water, which leads to better plant growth and greater tolerance to pathogens [32, 33]. Thus, we aimed to assess the effectiveness of organic amendments such as poultry refuse, mustard oilcake, Trichocomposts in the management of root-knot nematode of onion and to increase plant growth and yield of onion.

\section{Materials and Methods}

The performance of organic soil amendments viz. poultry refuse, mustard oilcake, rice bran and saw dust and Trichocomposts and Furadan 5G for the management of root knot nematode, Meloidogyne spp. was investigated in the field experiments at three cropping seasons during 2013-14, 201415 and 2015-16.

\subsection{Tricho-Compost Preparation}

Isolated Trichoderma harzianum (TM7) was initially multiplied on substrate containing a mixture of rice bran, wheat bran and mustard oilcake to obtain a formulated $T$. harzianum. The formulated T. harzianum was used for mass multiplication in two different mixtures of cow dung based compost materials. One of those composts contained cow dung and rice bran and the other contained a mixture of cow dung, rice bran and poultry manure. The formulated Trichoderma was added in between two layers of compost materials and kept for 45-50 days maintaining the moisture content approximately $60-70 \%$ for rapid multiplication of $T$. harzianum in the compost materials. Based on compost materials used in composting these composts were designated as Tricho-compost-1 and Tricho-compost-2.

\subsection{Field Experiment}

The field trials were conducted in the fields of Plant Pathology Division, BARI, Gazipur during 2013-14, 2014-15 and 2015-16 cropping years. There was 8 treatments namely i) Furadan (F) 5G@45 kg/ha, ii) Poultry refuse@5 t/ha iii) Mustard oilcake@600kg/ha, iv) Rice husk@3t/ha,v) Saw dust@3t/ha, vi) Tricho-compost-1@3 t/ha and vii) Trichocompost-2@3 t/ha viii) Control. The field experiments were laid out in randomized complete block design (RCBD) with 3 replications. The unit plot size was $2 \mathrm{~m} \times 3 \mathrm{~m}$ keeping $1 \mathrm{~m}$ distance from plot to plot. Standard cultivation procedures recommended by BARI were followed to grow onion with little modification. The experimental land was prepared with proper tillage and fertilizers were added during final land preparation. Requisite amount of poultry refuse, mustard oil cake, rice bran and sawdust were incorporation with the soil 3 weeks before transplanting of onion seedlings whereas Tricho-composts were added in the soils 5 days before seedling transplanting. After application, the organic materials were properly mixed with the soil and kept moist for proper decomposition. Furadan $5 \mathrm{G}$ was added at the time of seedling transplanting. To ensure inocula of the nematode, chopped severely galled roots of tomato infected with Meliodogyne spp were mixed with the furrow soils@200 $\mathrm{gm}^{-2}$ just before seedling transplanting. Forty five days old onion seedlings cv. Bari-piraz-1 grown on sterilized soils was transplanted in the experimental plots maintaining row to row and plant to plant distance of $15 \mathrm{~cm}$ and $10 \mathrm{~cm}$, respectively. During crop season necessary weeding, irrigation and other intercultural operations were done as per recommendation of the crop.

\subsection{Data Collection}

Data on plant height, plant weight, root length and yield were recorded. Gall index was recorded after final harvesting of onion according to $0-10$ scale Zeck [34]. Data were analysis by using MSTATC program following ANOVA. Treatment means computed using least significant difference (LSD) test.

\section{Results}

\subsection{Severity of Root-Knot Disease Severity}

In all the years, the severity of root-knot disease of onion was reduced significantly over control due to treatment of soil with poultry refuse (PR), Tricho-composts, mustard oilcake (MOC) as well as rice bran, saw dust and application of Furadan 5G. In the first year, the maximum average gall index value of 3.57 was recorded in the control plot. It was reduced to 1.33 to 2.03 due to treatments with organic amendments and the Furadan 5G. The lowest severity of root-knot disease of onion was recorded from the treatment with Tricho-compost-2, which was followed by poultry refuse, Furadan 5G, mustard oilcake and Tricho-compost-1 (Table 1). Soil treatment with Tricho-compost-2 gave the 
highest reduction of root-knot severity $60.80 \%$ compared to control followed by poultry refuse, Furadan $5 \mathrm{G}$, mustard oilcake and Tricho-compost-1 where the reduction of rootknot disease severity was $60.78 \%, 59.94 \%, 57.98 \%$ and $57.14 \%$, respectively.

In the second year, the highest gall index value of 2.73 was found in control plot and the values were reduced to 1.20 to 1.60 due to application of different treatments. The reduction in disease severity was significant compared to control. The maximum reduction was obtained with poultry refuse $60.80 \%$ /ha followed by Tricho-compost-1 and Trichocompost-2 where the reduction was $56.04 \%$. The least effective treatment to reduce root galling was saw dust followed by rice bran and Furadan $5 \mathrm{G}$ (Table 1).

In the third year, all the treatments gave significantly similar effect in reducing root-knot disease severity over control. The highest gall index value of 3.46 was recorded in control plot and the values were reduced to 1.24 to 1.75 due to application of different treatments. The highest reduction of root-knot disease severity $64.16 \%$ was observed in poultry refuse followed by Furadan 5G, Tricho-compost-2, Trichocompost-1 and mustard oilcake where the reduction of rootknot disease severity was $63.29 \%, 63.29 \%, 63.01 \%$ and $59.54 \%$, respectively (Table 1).

Table 1. Effect of soil treatment with organic amendments, Tricho-composts and a nematicide on the severity of root -knot disease (Meloidogyne spp) of onion.

\begin{tabular}{|c|c|c|c|c|c|c|}
\hline \multirow{2}{*}{$\begin{array}{l}\text { Organic amendments, Tricho- } \\
\text { composts and Furadan } 5 \mathrm{G} \text { with dose }\end{array}$} & \multicolumn{3}{|c|}{ Gall index (0-10 scale) } & \multicolumn{3}{|c|}{ Reduction of disease severity over control (\%) } \\
\hline & 2012-13 & 2013-14 & 2014-15 & 2012-13 & 2013-14 & 2014-15 \\
\hline Furadan5G@45kg/ha & $1.43 \mathrm{c}$ & $1.47 \mathrm{~b}$ & $1.27 \mathrm{~b}$ & 59.94 & 46.15 & 63.29 \\
\hline Poultry refuse@5t/ha & $1.40 \mathrm{c}$ & $1.07 \mathrm{c}$ & $1.24 \mathrm{~b}$ & 60.78 & 60.80 & 64.16 \\
\hline Mustard oilcake@0.6 t/ha & $1.50 \mathrm{c}$ & $1.53 \mathrm{~b}$ & $1.40 \mathrm{~b}$ & 57.98 & 45.05 & 59.54 \\
\hline Ricebran@3t/ha & $1.63 \mathrm{bc}$ & $1.57 \mathrm{~b}$ & $1.50 \mathrm{~b}$ & 54.34 & 42.49 & 56.65 \\
\hline Sawdust@3t/ha & $2.03 \mathrm{~b}$ & $1.60 \mathrm{~b}$ & $1.75 \mathrm{~b}$ & 43.14 & 41.39 & 49.42 \\
\hline Tricho-compost-1@3t/ha & $1.53 \mathrm{c}$ & $1.20 \mathrm{c}$ & $1.28 \mathrm{~b}$ & 57.14 & 56.04 & 63.01 \\
\hline Tricho-compost-2@3t/ha & $1.33 \mathrm{c}$ & $1.20 \mathrm{c}$ & $1.27 \mathrm{~b}$ & 62.75 & 56.04 & 63.29 \\
\hline Control & $3.57 \mathrm{a}$ & $2.73 \mathrm{a}$ & $3.46 \mathrm{a}$ & - & - & - \\
\hline $\operatorname{LSD}(\mathrm{P}=0.05)$ & 0.443 & 0.235 & 0.303 & - & - & - \\
\hline CV $(\%)$ & 14.01 & 8.64 & 10.67 & - & - & - \\
\hline
\end{tabular}

Values within the same column with a common letter do not differ significantly $(\mathrm{P}=0.05)$

\subsection{Plant Growth}

Average plant growth of onion under control was $42.09 \mathrm{~cm}$ plant $^{-1}$ in the first year, $42.27 \mathrm{~cm} \mathrm{plant}^{-1}$ in the second year and $31.45 \mathrm{~cm} \mathrm{plant}^{-1}$ in the third year. Soil amendments Tricho-composts, PR, MOC, rice bran, saw dust and Furadan $5 \mathrm{G}$ increased the parameter to $46.31-56.90 \mathrm{~cm} \mathrm{plant}^{-1}$ in the first year, $53.67-58.27 \mathrm{~cm} \mathrm{plant}^{-1}$ in the second year and $38.45-50.32 \mathrm{~cm} \mathrm{plant}^{-1}$ in the third year. In the first year, the highest plant height was obtained with Tricho-compost-2 followed by PR, Tricho-compost-1 and MOC. Lower increase in plant height over control was recorded under the treatment with Furadan $5 \mathrm{G}$ followed by rice bran and saw dust. In the second year, all the treatment gave significantly similar effect in increasing plant height compared to control. Higher plant height was recorded from Tricho-compost-2 followed by PR, Tricho-compost-1, MOC, Furadan 5G, saw dust and rice bran. In the third year, the maximum plant height was recorded from plots treated with Tricho-compost2 followed by PR, Tricho-compost-1 and MOC. It was almost identical to the plant height recorded from plots treated with Tricho-compost-2, PR, Tricho-compost-1 and MOC. The least effective treatment to increase plant height was sawdust followed by rice bran and Furadan $5 \mathrm{G}$ (Table 2).

Table 2. Effect of soil treatment with organic amendments, Tricho-compost and a nematicide on the plant growth of onion in soil inoculated with Meloidogyne spp.

\begin{tabular}{|c|c|c|c|c|c|c|}
\hline \multirow{2}{*}{$\begin{array}{l}\text { Organic amendments, Tricho- } \\
\text { composts and Furadan } 5 \text { G with dose }\end{array}$} & \multicolumn{3}{|c|}{ Plant height (cm) } & \multicolumn{3}{|c|}{ Plant weight (gplant $\left.{ }^{-1}\right)$} \\
\hline & 2012-13 & 2013-14 & 2014-15 & 2012-13 & 2013-14 & 2014-15 \\
\hline Furadan5G@45kg/ha & $50.05 \mathrm{bc}$ & $53.87 \mathrm{a}$ & $42.83 \mathrm{c}$ & $40.90 \mathrm{~cd}$ & $42.13 \mathrm{de}$ & $35.66 \mathrm{ab}$ \\
\hline Poultry refuse@ 5 t/ha & $55.67 \mathrm{a}$ & $56.67 \mathrm{a}$ & $48.17 \mathrm{ab}$ & $54.45 \mathrm{ab}$ & $58.00 \mathrm{ab}$ & 40.78 a \\
\hline Mustard oilcake@0.6 t/ha & $54.13 \mathrm{ab}$ & $55.93 \mathrm{a}$ & $46.09 \mathrm{~b}$ & $49.90 \mathrm{abc}$ & $50.53 \mathrm{bcd}$ & $35.89 \mathrm{ab}$ \\
\hline Rice bran@3t/ha & $46.31 \mathrm{c}$ & $53.67 \mathrm{a}$ & $42.39 \mathrm{c}$ & $43.75 \mathrm{bc}$ & $41.20 \mathrm{de}$ & $30.85 \mathrm{~b}$ \\
\hline Sawdust@3t/ha & $49.65 \mathrm{bc}$ & $53.73 \mathrm{a}$ & $38.45 \mathrm{~d}$ & $44.46 \mathrm{bc}$ & 43.07 cde & $30.67 \mathrm{~b}$ \\
\hline Tricho-compost-1@3t/ha & $53.05 \mathrm{ab}$ & $56.67 \mathrm{a}$ & $47.72 \mathrm{ab}$ & $50.76 \mathrm{abc}$ & $53.47 \mathrm{bc}$ & $39.66 \mathrm{a}$ \\
\hline Control & $42.09 \mathrm{c}$ & $42.27 \mathrm{~b}$ & $31.45 \mathrm{e}$ & $32.93 \mathrm{~d}$ & $38.80 \mathrm{e}$ & $24.08 \mathrm{c}$ \\
\hline $\operatorname{LSD}(\mathrm{P}=0.05)$ & 4.89 & 5.717 & 2.768 & 10.04 & 10.29 & 5.889 \\
\hline $\mathrm{CV}(\%)$ & 5.45 & 6.06 & 5.65 & 12.23 & 12.01 & 9.67 \\
\hline
\end{tabular}

Values within the same column with a common letter do not differ significantly $(\mathrm{P}=0.05)$

In first year, the plant weight of onion was $32.93 \mathrm{~g} \mathrm{plant}^{-1}$ under control. It increased to $40.90-57.69 \mathrm{~g} \mathrm{plant}^{-1}$ due to treatments with Tricho-composts, PR, MOC, rice bran, sawdust and Furadan 5G. The highest plant weight was achieved with Tricho-compost-2 followed by PR, Trichocompost-1 and MOC. The least effective treatment to 
increase plant weight was sawdust, which was followed by rice bran and Furadan 5G. More or less similar trend was also observed in the second and third year trials. In second year, the lowest plant weight of onion was $38.80 \mathrm{~g} \mathrm{plant}^{-1}$ recorded in the control. Soil amendment with Tricho-compost-2 gave the highest plant weight $64.27 \mathrm{~g} \mathrm{plant}^{-1}$ followed by soil treatment with PR, Tricho-compost-1 and MOC where the plant weight was 58.00, 53.47 and $50.53 \mathrm{~g}$ plant $^{-1}$, respectively (Table 2). The least effective treatment was sawdust followed rice bran by Furadan $5 \mathrm{G}$ and sawdust where the plant weight was $41.20,42.13$ and 43.07 g plant $^{-1}$, respectively (Table 2 ). In the third year, soil treated with Tricho-compost-2, PR and Tricho-compost-1 gave the higher plant weight which was followed by soil treated with MOC and Furadan $5 \mathrm{G}$. The lowest plant weight was recorded from control (Table 2).

\subsection{Root Growth}

Amendment of soil with Tricho-composts, PR, MOC, rice bran and sawdust and application of Furadan $5 \mathrm{G}$ showed positive effects on root growth of onion as compared to control. In first year, the minimum root length of 5.95 $\mathrm{cm} /$ plant was recorded under control and the maximum root length of $8.80 \mathrm{~cm}$ was achieved with Tricho-compost-1 followed by the treatments with Tricho-compost-2 and PR giving 8.66 and $8.17 \mathrm{~cm}$ root length, respectively (Table 3 ). Other treatments viz. soil amendment with MOC, rice bran and saw dust and application of Furadan $5 \mathrm{G}$ also increased root length over control within the range of 7.32-7.63 $\mathrm{cm} /$ plant. In second year, root length under control was 6.33 $\mathrm{cm} /$ plant. It was increased to $8.33-10.27 \mathrm{~cm} /$ plant due to application of different treatments.

Table 3. Effect of soil treatment with organic amendments, Tricho-compost and a nematicide on the root growth of onion in soil inoculated with Meloidogyne spp.

\begin{tabular}{|c|c|c|c|}
\hline \multirow{2}{*}{$\begin{array}{l}\text { Organic amendments, Tricho-composts and } \\
\text { Furadan } 5 \mathrm{G} \text { with dose }\end{array}$} & \multicolumn{3}{|c|}{ Root length (cm) } \\
\hline & 2012-13 & 2013-14 & 2014-15 \\
\hline Furadan 5G@45kg/ha & $7.62 \mathrm{~b}$ & $8.53 \mathrm{a}$ & $6.71 \mathrm{~d}$ \\
\hline Poultry refuse@5t/ha & $8.17 \mathrm{ab}$ & $10.13 \mathrm{a}$ & $8.67 \mathrm{ab}$ \\
\hline Mustard oilcake@0.6t/ha & $7.63 \mathrm{~b}$ & $8.73 \mathrm{a}$ & $7.72 \mathrm{bcd}$ \\
\hline Ricebran@3t/ha & $7.32 \mathrm{~b}$ & $9.53 \mathrm{a}$ & $6.61 \mathrm{~d}$ \\
\hline Saw dust@3t/ha & $7.47 \mathrm{~b}$ & $8.33 \mathrm{a}$ & $7.31 \mathrm{~cd}$ \\
\hline Tricho-compost-1@3t/ha & $8.80 \mathrm{a}$ & $10.27 \mathrm{a}$ & $8.33 \mathrm{bc}$ \\
\hline Tricho-compost-2@3t/ha & $8.66 \mathrm{a}$ & $10.13 \mathrm{a}$ & $9.74 \mathrm{a}$ \\
\hline Control & $5.95 \mathrm{c}$ & $6.33 \mathrm{~b}$ & $5.13 \mathrm{e}$ \\
\hline $\operatorname{LSD}(\mathrm{P}=0.05)$ & 0.875 & 1.867 & 1.139 \\
\hline CV $(\%)$ & 6.50 & 11.85 & 8.64 \\
\hline
\end{tabular}

Values within the same column with a common letter do not differ significantly $(\mathrm{P}=0.05)$

In the third year, the lowest root length was $5.13 \mathrm{cmplant}^{-1}$ recorded in control. The maximum root length was 9.74 cmplant $^{-1}$ achieved in Tricho-compost- 2 treatment followed by PR, Trichocompost-1 and MOC where root length was $8.67,8.33$ and $7.72 \mathrm{cmplant}^{-1}$, respectively. In this year the least effective treatment was rice bran followed by Furadan $5 \mathrm{G}$ and sawdust (Table 3).

\subsection{Crop Yield}

Organic soil amendments with PR and MOC, Trichocomposts and Furadan 5G gave appreciable increase in onion yield per hectare in all the years (Table 3). In first year, the lowest yield of $11.67 \mathrm{t} /$ ha was found under control. The yield was increased to $13.33-17.78 \mathrm{t} / \mathrm{ha}$ due to application of different treatments with $\mathrm{PR}$, Tricho-composts, MOC, rice bran, sawdust and Furadan 5G. The maximum yield increased $34.36 \%$ compared to control was obtained with PR followed by Tricho-compost-2, Tricho-compost-1 and MOC where yield was increased $32.23 \%, 29.99 \%$ and $29.99 \%$, respectively over control (Table 4). Efficacy of four treatments to increase yield was statistically identical. The lowest increase was achieved with Furadan $5 \mathrm{G}$ followed by rice bran and sawdust where yield was increased $12.45 \%$, $14.63 \%$ and $14.63 \%$, respectively compared to control.

Table 4. Effect of soil treatment with organic amendments, Tricho-composts and a nematicide on the yield of onion in soil inoculated with Meloidogyne spp.

\begin{tabular}{|c|c|c|c|c|c|c|}
\hline \multirow{2}{*}{$\begin{array}{l}\text { Organic amendments, Tricho-composts } \\
\text { and Furadan 5G with dose }\end{array}$} & \multicolumn{3}{|c|}{ Yield $\left(\right.$ tha $\left.^{-1}\right)$} & \multicolumn{3}{|c|}{ Yield increased over control (\%) } \\
\hline & 2012-13 & 2013-14 & 2014-15 & 2012-13 & 2013-14 & 2014-15 \\
\hline Furadan 5G@45kg/ha & $13.33 \mathrm{~b}$ & $12.09 \mathrm{abc}$ & $10.55 \mathrm{c}$ & 12.45 & 23.57 & 14.50 \\
\hline Poultry refuse@5t/ha & $17.78 \mathrm{a}$ & $13.87 \mathrm{a}$ & $12.67 \mathrm{ab}$ & 34.36 & 33.38 & 28.81 \\
\hline Mustard oilcake@0.6t/ha & $16.67 \mathrm{a}$ & $12.22 \mathrm{abc}$ & $11.47 \mathrm{bc}$ & 29.99 & 24.39 & 21.36 \\
\hline Rice bran@3t/ha & $13.67 \mathrm{~b}$ & $11.38 \mathrm{bcd}$ & $10.89 \mathrm{c}$ & 14.63 & 18.80 & 17.17 \\
\hline Saw dust@3t/ha & $13.67 \mathrm{~b}$ & $11.02 \mathrm{~cd}$ & $10.44 \mathrm{c}$ & 14.63 & 16.15 & 13.60 \\
\hline Tricho-compost-1@3t/ha & $16.67 \mathrm{a}$ & $13.60 \mathrm{ab}$ & $12.22 \mathrm{ab}$ & 29.99 & 32.06 & 26.19 \\
\hline Control & $11.67 \mathrm{c}$ & $9.24 \mathrm{~d}$ & $9.02 \mathrm{~d}$ & - & - & - \\
\hline $\operatorname{LSD}(\mathrm{P}=0.05)$ & 1.64 & 2.13 & 1.198 & - & - & - \\
\hline CV $(\%)$ & 6.22 & 10.00 & 6.07 & - & - & - \\
\hline
\end{tabular}

Values within the same column with a common letter do not differ significantly $(\mathrm{P}=0.05)$ 
In the $2^{\text {nd }}$ year, average yield of onion was $9.24 \mathrm{t} / \mathrm{ha}$ under control and 11.02 to $13.95 \mathrm{t} / \mathrm{ha}$ under treated plots. Soil Treated with Tricho-compost- 2 and PR gave the maximum yield which was followed by soil amendment with Trichocompost-1, MOC and Furadan 5G. The yield increased over control was significant under all treatments with Trichocomposts, PR, MOC and Furadan 5G. The highest yield increased over control was obtained with Tricho-compost-2 $33.76 \%$ followed by PR, Tricho-compost-1, MOC and Furadan 5G where yield was $33.38 \%, 32.06 \%, 24.39 \%$ and $23.57 \%$, respectively higher then control. In the $3^{\text {rd }}$ year, the highest yield was $12.78 \mathrm{t} / \mathrm{h}$ obtained with Tricho-compost- 2 a followed by PR, Tricho-compost-1 and MOC where yield was $12.67,12.22$ and 11.47 tha $^{-1}$. The least effective treatment was sawdust followed by Furadan $5 \mathrm{G}$ and rice bran where yield was $10.44,10.55$ and 10.89 tha $^{-1}$, respectively. The lowest yield of 9.02 tha $^{-1}$ obtained under control. Soil treated with Tricho-compost-2 gave $29.42 \%$ higher yield over control followed by PR, Tricho-compost-1 and MOC where yield was $28.81 \%, 26.19 \%$ and $21.36 \%$ higher than control. The lowest increase of yield was achieved with sawdust followed by Furadan $5 \mathrm{G}$ and rice bran where yield was $13.60 \%, 14.50 \%$ and $17.17 \%$, respectively higher compared to control.

\section{Discussion}

The present study showed that amending the soil with organic materials, namely PR, MOC, sawdust, rice bran and two different Tricho-compost, suppressed the disease severity of root-knot nematode caused by Meloidogyne spp. of onion with a concomitant increase in the growth and yield of onion. This is in agreement with previous findings of Chindo and Khan [35] and Nico et al. [36], who used poultry manure and decomposed agro-industrial waste products, namely composed dry cork, dry grape marc, dry olive marc and rice husk, as soil amendments for the management of Meloidogyne spp. Nico et al. [36] reported that composted agro-industrial waste reduced the populations of Meloidogyne spp. by $24.4 \%$ to $87.9 \%$. Beneficial effects of organic wastes on nematode control and crop growth were also observed by other researchers [32, 36-40]. Among all the treatments PR and Tricho-compost-2 recorded the highest improvement in plant growth and maximum reduction in the root knot disease severity. Other treatments viz., Trichocompost-1, MOC, rice bran and sawdust also showed significant enhancement in plant growth of onion and reduction in the severity of root knot nematode. The potential of all treatments to inhibit nematode activity resulted in increased yield of onion. This beneficial relationship and improvement in plant growth parameters may be due to release of allele-chemicals and nutrients on the decomposition of the amendment that enhance the beneficial microflora of the soil rhizosphere that act as promoter of growth activity. While the reduction in nematode infestation may be due to release of some toxic chemicals which either disrupt the life cycle of the nematode or lesser down the infectivity of the juvenile.

Ibrahim and Ibrahim [41] observed that the soil amended with manures greatly suppressed the nematode reproduction (egg mass production). Umar and Jada [42] also used goat manure that inhibited the growth and development of Meloidogyne incognita in pot tests. Siddiqui et al. [43]; Verma et al. [44] also reported that application of organic manuring resulted in less galling and nematode multiplication. Bulluck et al. [45] reported that soil amendments had a large impact on nematode community structure and diversity. Costa et al. [46] observed reduced nematode egg production when poultry manure extracts were applied to $M$. incognita-inoculated tomato plants. Devi and Hassan [47] reported that all treatments of $T$. viride, farmyard and poultry manures reduced nematode gall formation. Sundararaju et al. [48] reported that the population of root knot nematode (Meloidogyne incognita) was significantly lower in plants that received poultry manure.

In regard to mode of action of organic manure against soil nematode, Lazarovits et al. [49] reported that high-nitrogencontaining organic amendments such as poultry or cattle manure had an immediate suppressive effect on soil nematodes as a result of ammonia release immediately after initiation of microbial decomposition. Also, Oka and Pivonia [50] stated that organic fertilizers contain ammonia and formulations releasing this form of nitrogen in the soil that can suppress nematode populations. Mbah and Onweremadu [51] reported that farming practices such as organic fertilizing can be geared to conserve and promote soil aggregations that impede the nematode larvae movement.

Compost is an aerobically decomposed organic material derived from plant biomass and animal source. It is rich in available soil nutrients and often used in gardens, landscaping, horticulture and agricultural field crops, to build soil fertility. Physical and chemical properties of the soil are improved by the use of compost, which ultimately increases crop yield [52]. Nematode suppression with compost amendments may involve different mechanisms, such as direct toxicity of degradation products, an increase of natural nematode-antagonist micro-organisms on the compost substrate or even the induction of systemic acquired resistance in plants [53 and 54]. Olabiyi and Oladeji [55] reported that the application of different composts prepared through Rapid Composting Technology with Trichoderma harzianum as decomposer significantly reduced the erratic nematode population changes and also have significant effect on the growth and yield of crop.

\section{Conclusion}

Root knot nematodes of onion caused by M. incognita and M. graminicola are become destructive and most prevalent in the tropical and sub-tropical countries where temperatures are 18 to $27^{\circ} \mathrm{C}$. In this study different sources of organic materials viz. poultry refuse, mustard oil cake, rice bran, sawdust and Tricho-composts, and a nematicide Furadan $5 \mathrm{G}$ were evaluated against root nematode, Meloidogyne 
incognita on the major spices onion, Allium cepa $\mathrm{L}$ in the field. The findings of the present investigations revealed that all the organic soil amendments and nematicide significantly reduced root knot disease severity and increased plant growth as well as yield of onion. Among the treatments Trichocomposts and poultry refuse appeared to be the best amendments for root knot nematode reduction and significantly influenced the growth of the onion with the highest yield. Saw dust, rice bran and nematicide Furadan 5G were also proved to be better amendment for reduction of root knot nematode which enhanced plant growth and increased yield of onion. These results suggest that exploitation of organic soil amendment in nematode management would be a useful control measure in onion production in Bangladesh.

\section{Acknowledgements}

This research was supported by Bangladesh Agricultural Research Institute, Gazipur. The authors grateful to Dr. M. A. Rahman, former Chief Scientific Officer and Head, Plant Pathology Division, BARI for their fruitful discussion. Thanks go to Mr. Md. Abdur Razzak and Mr. Zamil Akter (Scientific Assistant) for their assistance in this research work.

\section{References}

[1] BBS. 2015. Yearbook of Agricultural Statistics, Bangladesh Bureau of Statistics, Statistics Information Division, Ministry of Planning, Government of the People's Republic of Bangladesh, Dhaka, Bangladesh. Pp 133.

[2] FAO. 1998. FAO Yearbook, Production 1998. Food and Agriculture Organization of United Nations, Rome, Italy. 51: 135-136.

[3] Munoz, D. C. I., Martinez, J. J. P. and Perez, A. P. 1984. Onion seed production under tropical conditions. Humbalst Inst. Fund. Res. Trop. Agric. Acad. Sci. 10 (2): 42-45.

[4] Ahmed, M. U. and Hossain, M. M. 1985. Final report of project crop disease survey and establishment of a herbarium at BARI, Plant Path. Div. BARI, Joydebpur, pp 1670.

[5] Meah, B. and Khan, A. A. 1987. Checklist of vegetables and fruit diseases in Bangladesh. Dept. of plant Path. Bangladesh Agril. Univ., Mymensingh. 22 pp.

[6] Bose, T. K. and Som, G. M. 1986. Vegetable crops in India. Naya Prokash, Calcutta, India. 567-569 pp.

[7] Castellanes-Linares, J. J., Auchet-Jencens, F. and GarciaCorreosa, I. 1988. Effect of Alternaria porri. (EII.) Cif. On onion seed production under experimental conditions in Cuba. In Rev. Pl. Pathol. 67: 2730.

[8] Khan, A., Khan, H. A. and Bilqees, F. M. 1992. Aglenchus siddiqii a new nematode species from Karachi, Pakistan Nematological Abstracts 062-01078.

[9] Khan, A., Saeed, M. and Rajput, T. 1985. Pathogenic effect of various population levels of Helicotylenchus indicus on tomato and onion seedlings. Helminthological Abstracts Series B. 057-00602.
[10] Khan, F. A. and Omoyi, P. I. 1985. Reaction of selected cultivars of onion to root-knot nematode in Northern Nigeria. Plant Breeding Abstracts 056-09974.

[11] Doucet, M. E., De-Ponce, E. L., Dapoto, G., Junyent, R. G. and Giganti, H. 1994. Association of Meloidogyne incognita and onion in the valley of Rio Negro and Neuquen, Argentina, Nematological Abstracts 063-01483.

[12] Romney, R. K., Andersona, J. L. and Griffin, G. D. 1974. Effectos of DCPA on seedlings infection by root-knot nematode. Helminthological Abstracts-Series-B-1975-04400856.

[13] Westerdhal, B. B., Anderson, C. E., Noffsinger, E. M., Carlson, H. L., Roberts, P. A. and Weiner, A. 1993. Pathogenicity of the Columbia root-knot nematode to onions. Plant Dis. 77 (8): 847.

[14] Babu, R. S. and Vadivelu, S. 1989. Pathogenicity of root-knot nematode on onion. Int. Nematol. Network Newsl. 6 (1): 1113.

[15] Monteiro, A., Barbosa-Ferroz, R. and Ferraz, I. C. C. 1988. First record and preliminary information on the host range of Meloidogyne graminicola in Brazil. Helminthological Abstracts Series B. 058-00667.

[16] Lordello, L. G. E., Mello-Filho, A. De. T. and Mello Filho, De-Toledo. 1971. Occurrence of nematodes under onion, Soils and Fertilizers. 036-00882.

[17] Vannacci, G. and Gullino, M. L. 2000. Use of biological agents against soil borne pathogens: Results and limitations. Acta Hortic., 532: 79-8718.

[18] Atungwu, J. J. 2005. An overview of the impact of organic manure as plant parasitic nematode suppressant. Proceedings, 1st National Conference on Organic Agriculture, UNAAB, Abeokuta, Nigeria, October 25-28, pp. 149-157.

[19] Castillo, P., Nico, A. I., Azcon-Aguilar, C., Del Rio Rincon, C., Calvet, C. and Jimenez-Diaz, R. M. 2006. Protection of olive planting stocks against parasitism of root-knot nematodes by arbuscular mycorrhizal fungi. Plant Pathol., 55 (5): 705-713. DOI: 10.1111/j.1365-3059.2006.01400.

[20] Riga E., Lacey, L. and Guerra, N. 2007. The potential of the fungus Muscodor albus as a bio-control agent against economically important plant-parasitic nematodes of potatoes in Washington State J. Nematol., 39: 98-98.

[21] Sasanelli N., Takács, A., D’addabbo, T., Biró, I. and Malov, X. 2009. Influence of arbuscular mycorrhizal fungi on the nematicidal properties of leaf extracts of Thymus vulgaris L. Helminthologia, 46: 230-240. DOI: 10.2478/s11687-0090043-6

[22] Riga, E. 2011. The effects of Brassica green manures on plant parasitic and free living nematodes used in combination with reduced rates of synthetic nematicides. J. Nematol., 43: 119121.

[23] Akhtar, M. 1997. Current options in integrated management of plant-parasitic nematodes. Integrated Pest Manag. Rev., 2: 187-797. DOI: 10.1023/A: 1018409303298.

[24] Hassan M. A., Chindo, P. S., Marley, P. S. and Alegbejo, M. D. 2010. Management of root knot nematodes (Meloidogyne spp.) on tomato (Lycopersicon lycopersicum) using organic wastes in Zaria, Nigeria. Plant Protec. Sci., 46: 34-39. 
[25] Fiorini C. V. A., Gomes, L. A. A., Libânio, R. A., Maluf, W. R., Campos, V. P., Licursi, V., Moretto, P., Souza, L. A. and Fiorini, I. V. A. 2007. Identificação de famílias F2: 3 de alface homozigotas resistentes aos nematoides das galhas. Horticultura Brasileira 25: 509-513.

[26] Silva R. R., Gomes, L. A. A., Monteiro, A. B., Maluf, W. R., Carvalho Filho, J. L. S. and Massaroto, J. A. 2008. Linhagens de alface-crespa para o verão resistentes ao Meloidogyne javanica e ao vírus mosaico-da-alface. Pesquisa Agropecuária Brasileira 43: 1349-1356.

[27] Ferreira S., Vieira, V. L. F., Gomes, L. A. A., Maluf, W. R. and Carvalho Filho, J. L. S. 2011. Identificação de linhagens avançadas de alface quanto à resistência a Meloidogyne javanica. Ciência e Agrotecnologia 35: 270-277.

[28] Moraes S. R. G., Campos, V. P., Pozza, E. A., Fontanetti, A., Carvalho, G. J. and Maximiniano, C. 2006. Influência de leguminosas no controle de fitonematoides no cultivo orgânico de alface americana e de repolho. Fitopatologia Brasileira 31: 188-191.

[29] Santana S. M., Dias-Arieira, C. R., Biela, F., Cunha, T. P. L., Chiamolera, F. M., Roldi, M. and Abe, V. H. F. 2012. Antagonistic plants in the management of Meloidogyne incognita in sandy soil of vegetables growing areas. Nematropica 42: 287-294.

[30] Charchar J. M., Vieira, J. V., Oliveira, V. R. and Moita, A. W. 2009. Cultivo e incorporação de leguminosas, gramíneas e outras plantas no controle de Meloidogyne incognita raça 1 em cenoura 'Nantes'. Nematologia Brasileira 33: 139-146.

[31] Oka Y. 2010. Mechanisms of nematode suppression by organic soil amendments. Applied Soil Ecology 44: 101-115.

[32] Akhtar, M. and Malik, A. 2000. Roles of organic soil amendments and soil organisms in the biological control of plantparasitic nematoides: a review. Bioresource Technology 74: 35-47.

[33] González M., Gomez, E., Comese, R., Quesada, M. and Conti, M. 2010. Influence of organic amendments on soil quality potential indicators in an urban horticultural system. Bioresource Technology 101: 8897-8901.

[34] Zeck, M. W. 1971. A rating scheme for field evaluation of root knot nematode infestation. Planzenschuta-Nacht, 24: 141-144.

[35] Chindo, P. S. and Khan, F. A. 1990. Control of root-knot nematodes (Meloidogyne spp.) on tomato (Lycopersicon esculentum Mill.) with poultry manure. Tropical Pest Mangement, Vol. 36, (1990), No. 4, pp. 332-335,

[36] Nico A. I., Jimenez-Diaz, R. M. and Castilla, P. 2004. Control of root knot nematodes by composed agroindustrial wastes in potting mixtures. Crop Protection, 23: 581-587

[37] Abubakar, U. and Majeed Q. 2000. Use of Animal Manure for the control of root knot nematodes of tomato. Journal of Agriculture and Environment, 1 (12): 29-33.

[38] Tijani A. S. M., Mabagala R. B. and Mchimbi-Msolla, D. 2000. Efficiency of different control methods applied separately and in combination in managing root knot nematodes (Meloidogyne spp.) in common beans. European Journal of Plant Pathology, 106: 1-10.

[39] Nwanguma, E. I. and Awoderu, J. B. 2002. The relevance of poultry and pig droppings as nematode suppressants on okra and tomato in Ibadan, south-western Nigeria. Nigerian Journal of Horticultural Sciences, 6: 67-69.

[40] Abubakar, U. and Adamu T. 2004. Control of Meloidogyne incognita (Kofoid and White) Chitwood of tomato (Lycopersicon lycopersicum Karst) using camel dung. Journal of Tropical Biosciences, 47: 1-3.

[41] Ibrahim, A. A. M. and Ibrahim, I. K. A. 2000. Evaluation of non-chemical treatments in the control of Meloidogyne incognita on common bean. Pak. J. Nematol., 18 (1-2): 51-57.

[42] Umar, I. and Jada, M. Y. 2000. The efficacy of mixtures of two organic amendments (parkia seeds and goat manure) on the control of root knot nematodes (Meloidogyne incognita) on tomato (Lycopersicon esculentum). Global J. Pure and Applied Sci., 6 (2): 177-180.

[43] Siddiqui, Z. A., Iqbal, A. and Mahmood, I. 2001. Effects of Pseudomonas fluorescens and fertilizers on the reproduction of Meloidogyne incognita and growth of tomato. Applied Soil Ecol., 16 (2): 179-185.

[44] Verma, K. K., Jain, R. K. and Mehta, U. K. 1998. Effect of soil texture on growth of cotton plants under root-knot nematode infested conditions. International Symposium of the Afro-Asian Society of Nematologgist. p. 33, Coimbatore, India.

[45] Bulluck, L. R., Barker, K. R. and Ristaino, J. B. 2002. Influences of organic and synthetic soil fertility amendments on nematode trophic groups and community dynamics under tomatoes. Applied Soil Ecology, 21 (3): 233-250.

[46] Costa, M. J. N., Campos, V. P., Pfenning, L. H. and Oliveira, D. F. 2002. Pathogenicity and reproduction of Meloidogyne incognita in tomato plants (Lycopersicon esculentum) with application of fungal filtrates or plant and animal manure extracts. Nematologia Brasileira, 26 (1): 5-12.

[47] Devi, L. S. and Hassan, M. G. 2002. Effect of organic manures singly and in combination with Trichoderma viride against root knot nematode, Meloidogyne incognita of soybean (Glycine max L. Mrill). Indian J. Nematol., 32 (2): 190-192.

[48] Sundararaju, P., Mustaffa, M. M., Kumar, V., Cannayane, I. and Priya, B. T. 2002. Effect of organic farming on plant parasitic nematodes infesting banana cv. Karpuravalli. Current Nematol., 13 (1/2): 39-43.

[49] Lazarovits, G., Tenuta, M. and Conn, K. L. 2001. Organic amendments as a disease control strategy for soil borne disease of high-value agricultural crops. Australasian Plant Pathology, 30: 111.

[50] Oka, Y. and Pivonia, S. 2002. Use of ammonia-releasing compounds for control of the root-knot nematode. Nematology, 4: 65-71.

[51] Mbah, C. N. and Onweremadu, E. 2009. Effect of organic and mineral fertilizer inputs on soil and maize grain yield in an acid ultisol in Abakaliki-South Eastern Nigeria. American Eurasia J. Agron., 2 (1): 7-12.

[52] Martens, D. A. 2000. Management and crop residue influence soil aggregate stability. J. Environ. Qual. 29: 723-727.

[53] Stirling, G. R. 1991. Mode of action of organics amendments against nematode. In: Biological control of plant parasitic Nematodes. Progress, problems and prospects. C. A. B. international, pp. 170-185. 
[54] Zhang, M., Malhi, S. S., Panasuik, R. and Henriquez, B. 2011. Response of turfgrass growth in a black chernozemic soil amended with municipal solid/biosolid waste compost. J. Plant Nutrition 34: 183-205.
[55] Olabiyi, T. I. and Oladeji, O. O. 2014. Assessment of four compost types on the nematode population dynamics in the soil sown with okra. Int. J. of Organic Agric. Res. and Develop. 9: 146-155. 